\title{
WPS3229
}

\section{HOUSEKEEPING AND PLUMBING: THE INVESTABILITY OF EMERGING MARKETS}

\author{
JEPPE LADEKARL AND SARA ZERVOS*
}

\begin{abstract}
This paper looks at the investment allocation process employed by portfolio investors in emerging markets. In particular, it examines the first of a two-stage decision process: first, investors create a sub-set of investable countries to be analyzed later in further detail; second, they weigh expected returns versus risk and subsequently allocate their funds. This study hypothesizes that the determination of whether a country is investable or not is influenced by a number of factors, especially related to size, quality of "housekeeping" (macro policies, political economy, local financial markets, corporate governance, etc.) and efficiency of "plumbing" (legal and regulatory framework, custody, clearing and settlement, taxes, etc.). By interviewing many types of these investors in both the United States and the United Kingdom, we delve into their decision-making processes as well as attempt to uncover the factors they indicate matter most in defining the investable universe. We determine the relative importance of such housekeeping and plumbing factors while highlighting the role of external issues, such as index benchmarking and U.S. foreign policy. We recognize from the outset that the most profound effects on investment flows, or the required minimum expected returns, arise from improvements or deteriorations in macro policies. However, at the margin, improvements can be made in country policies that will, for a given macro situation, improve the ability of a country to attract international investment flows.
\end{abstract}

JEL Classification Code: F36, G11, G15, G18, H36, K22

Keywords: Portfolio Investors, Portfolio Flows, Emerging Markets, Investability, Investment allocation, Investment guidelines, Index Benchmark

\section{World Bank Policy Research Working Paper 3229, March 2004}

The Policy Research Working Paper Series disseminates the findings of work in progress to encourage the exchange of ideas about development issues. An objective of the series is to get the findings out quickly, even if the presentations are less than fully polished. The papers carry the names of the authors and should be cited accordingly. The findings, interpretations, and conclusions expressed in this paper are entirely those of the authors. They do not necessarily represent the view of the World Bank, its Executive Directors, or the countries they represent. Policy Research Working Papers are available online at http:/lecon.worldbank.org.

\footnotetext{
* Jeppe Ladekarl (jladekarl@worldbank.org), and Sara Zervos (szervos@worldbank.org) are both from the World Bank's Financial Sector Vice Presidency. The authors are grateful to Messrs. Glaessner, Jonasson, Lybek, Vittas, and numerous asset management professionals in London, New York and Boston who shared their insights and experiences and provided comments and suggestions. Alessandra Campanaro provided excellent research assistance.
} 


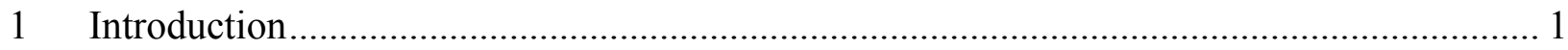

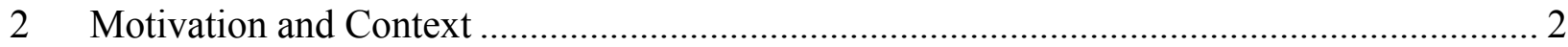

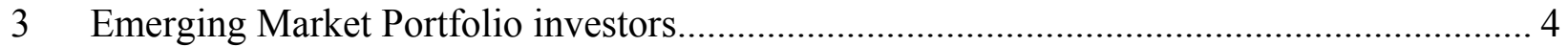

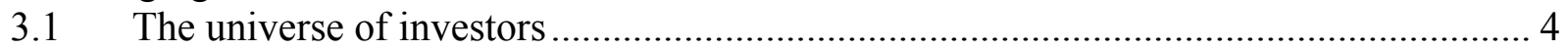

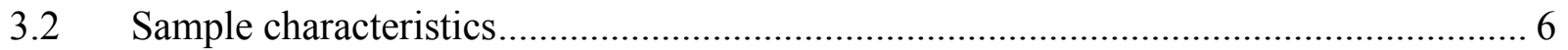

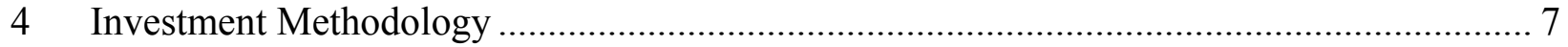

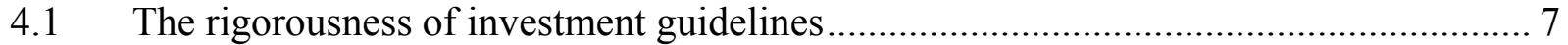

4.2 The role of data and models for investment decisions........................................... 8

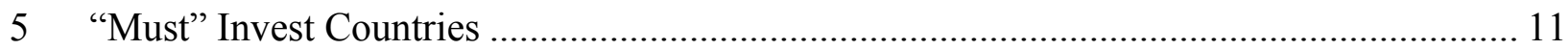

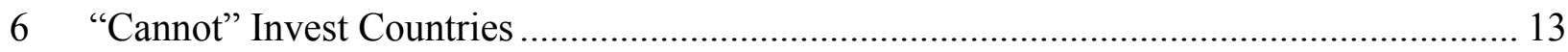

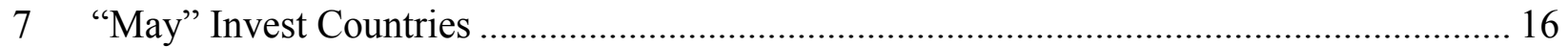

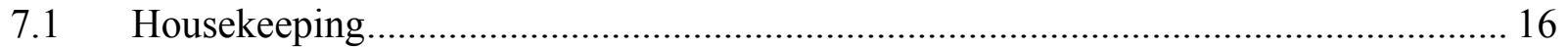

7.1.1 Macroeconomic conditions ........................................................................ 16

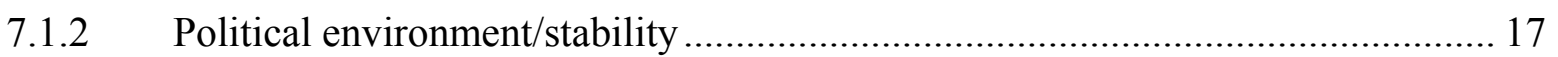

7.1.3 Quality of local financial markets............................................................... 17

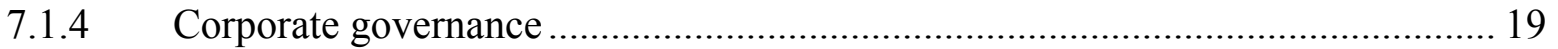

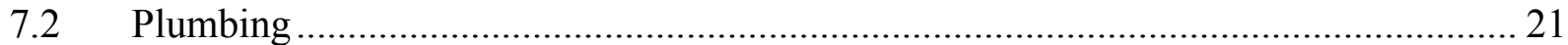

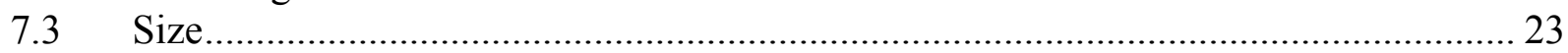

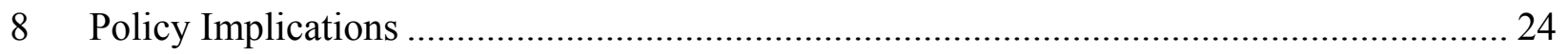

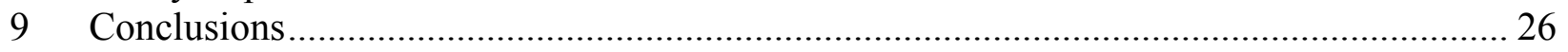

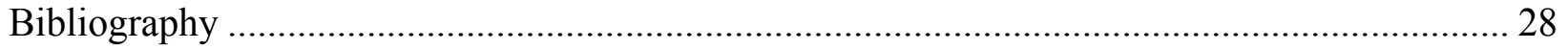


Tables:

Table 1: Number of countries by weight in key emerging market indices .............................. 13

Table 2: Selected factors influencing the investability decision........................................... 25

Figures:

Figure 1: Hypothetical Risk / Reward Tradeoff ............................................................... 10

Boxes:

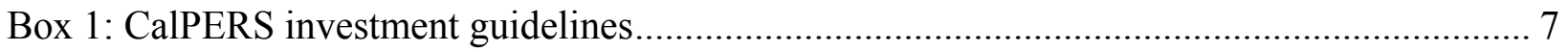

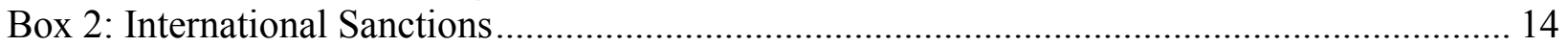

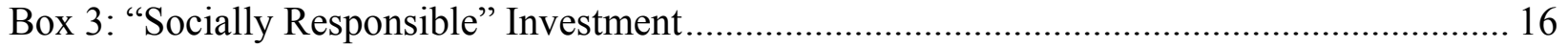

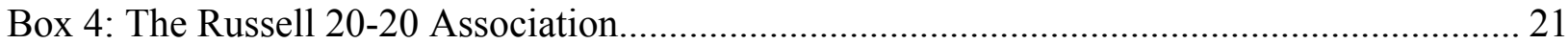

Appendixes:

Appendix 1 CALPERS Permissible Country List: Country and Market Factors....................... 31 


\section{INTRODUCTION}

Countries around the world vie for external investment flows, both portfolio and direct investment, to fund current account deficits. While most countries tend to prefer direct investments, due to their relatively more permanent nature, portfolio flows are nonetheless often an important source of financing. As such, countries will attempt to adapt various policies in an effort to impact the allocation of funds made by international portfolio investors. The success of these efforts depends on the factors that investors deem important, and the decision-making process they employ to allocate money. We propose that the investment allocation process employed by many of these investors is two-staged: first a sub-set of investable countries is created, to be analyzed later in further detail; second the calculation of expected return versus risk calculations is performed, followed by the allocation of funds among investable countries.

This paper is concerned with the factors influencing the first of these two stages: how investors determine the investability of a country. The paper hypothesizes that the determination of whether a country is investable is influenced by a number of factors, especially related to size (of the economy, the security issue, the investor), quality of "housekeeping" (macroeconomic policy framework, political economy, local financial markets, corporate governance, etc.) and efficiency of "plumbing" (legal and regulatory framework, custody, clearing and settlement, taxes, etc.). Unlike the majority of the academic literature relating to international capital flows, which uses flow data to derive the determinants of observable flows, this paper relies principally on interviews with several international portfolio investors (and their back-office teams) to shed light on the investment process in practice. The interviews focused on: governance arrangements (who decides what), investment methodology (how the decisions are taken), minimum infrastructure requirements (what minimum legal, regulatory, trading, depository and settlement arrangements are required), and ultimately the implicit or explicit lists of countries in the funds' investable universe. This paper seeks to identify the most important factors that in practice put a country on (or off) an investor's feasible set, and draws some policy implications for countries seeking to enter the radar screen of the international investor and attract capital flows.

We discovered that countries can be classified into the following three broad categories: "must invest", "may invest", and "cannot invest". "Must invest" countries are typically countries where international portfolio investors will invest no matter how good or bad the plumbing or housekeeping is. "Cannot invest" countries are typically countries under some kind of international investment embargo. "May invest" countries comprise the rest, where the quality of housekeeping and plumbing does have an effect on the investment flows. Our policy conclusions are mostly of interest to countries in this latter category. These are the countries that, through policy initiatives, can affect their attractiveness to international portfolio investors and move from being speculative and peripheral investments to the more stable and core parts of portfolios. However, we recognize from the outset that the most profound effects on investment flows, or the required minimum expected returns, arise from improvements or deteriorations in macroeconomic policies and political stability. That said, we do believe improvements can be made, which will, for a given macro situation, improve the ability of a country to attract international investment flows. 
Our policy conclusions are thus mainly concerned with what countries can do at the margin to improve their attractiveness through initiatives that impact the quality of the plumbing and/or housekeeping.

The paper is structured as follows. Section 2 provides some context to the paper in terms of academic literature and current market practices. Section 3 describes in a generic way the characteristics and investment philosophy of emerging market portfolio investors as well as the features of the specific investors interviewed for this study. Section 4 looks at the investment process: Who takes what decisions? What investment methodology is employed? What is the role of quantitative versus qualitative factors? Sections 5 to 7 present the key factors that impact the categorization of countries into either the "must", "cannot", or "may" invest category. Section 8 discusses policy implications for emerging markets given the observed behavior of portfolio investors, and section 9 concludes.

\section{MOTIVATION AND CONTEXT}

The nature and cause of international capital flows touches on many aspects of academic research. We see three strands of academic literature, in addition to current developments in actual asset management practices, related to this paper's topic. The first avenue has looked at determinates of global capital flows to and from markets. These studies often focus on interest rates, returns, and integration effects. Tesar and Werner $(1994,1995)$ report that U.S. interest rates and industrial production can explain part of equity flows from the U.S. to Latin America, while Bohn and Tesar (1996) show a positive correlation between portfolio equity flows and returns in the recipient country. The relationship between capital flows and equity returns has in addition been examined extensively by Warther (1995), Froot, O'Connell and Seasholes (2001) and Bekaert, Harvey and Lumsdaine (2002). Brennan and Cao (1997) look at an information asymmetry model and link equity flows to stock returns. Calvo, et al. (1993) find that global interest rates and business cycle conditions are the strongest factors driving flows into Latin America. While such macroeconomic variables do enter the investability decisions of the investors we interviewed, for the typical emerging market, they drive flows by creating an opinion of credit risk rather than determining global liquidity conditions.

A second strand of literature focuses on factors affecting the allocation of funds to individual countries. These often concentrate on correlating differences in macroeconomic conditions as well as structural features with observed portfolio flows. Gordon and Gupta (2003) attribute portfolio equity flows into India to both external factors (interest rates and stock returns) and internal factors (credit ratings). Aggarwal, Klapper and Wysocki (2003) link various country level characteristics (macro, legal, investor protection), firm qualities, and index effects to the investment allocations of U.S. mutual funds in emerging market equities. Gelos and Wei (2003) empirically test whether country and/or corporate transparency affects mutual fund positions in emerging markets. Gregorian (2003) is a study identifying which factors affect a country's ability to issue sovereign bonds internationally for the first time. A large subset of this avenue of research examines the implication of one country specific factor that influences capital flows: 
financial liberalization. Many papers argue that liberalization increases capital flows, which in turn can be linked to economic variables such as growth and investment. For example, Bekaert, Harvey and Lundblad (2001) demonstrate that equity market liberalizations lead to a one percent increase in annual real growth rates. Henry $(2000 \mathrm{a}, \mathrm{b})$ show that stock market liberalizations contribute to higher investment, and reduces the cost of capital in the country. More examples of the relationship between liberalization and financial development can be found in Bekaert (1995), Bekaert and Harvey $(1995,2000)$, as well as in Levine and Zervos (1998). As shown below, our paper touches on these topics as the degree of financial liberalization will affect the investors' ability to enter / exit a country, and can put a country off the investable list.

A third category of research explains fund management decisions in light of incentive schemes, trading strategies, herding behavior, etc. Kaminsky, Lyons and Schumkler (2000) look at the behavior of investors and managers, focusing on the motivations behind trading strategies. Cho, Kho and Stulz (1999) and Kim and Wei (2002) look at positive feedback trading and herding behavior by foreign investors. Finally, a paper by Borenszstein and Gelos (2000) presents findings on the degree of herding behavior in emerging markets, especially in times of crisis. In this paper we shed some light on how the behavior of the market participants at large, and benchmark driven fund managers in particular, influence investors' investability decisions.

Outside of academic literature, asset management practices have evolved toward more rule-based investment methodologies. For example, the California Public Employees' Retirement System (CalPERS), which manages around USD 145 billion globally, recently changed their permissible country list according to a new rigid methodology whereby a country must achieve a minimum score in order to be considered investable. Furthermore, public interest groups and academics have started to focus on analyzing and setting criteria for so-called "socially responsible" investments globally that also predefines an investable universe. For example, the UK Social Investment Forum, the Social Investment Forum in the US and the Dutch Association of Investment Analysts in cooperation with University of Nyenrode, have all carried out surveys of asset management practices in this area (Hummels and Timmer (2003), Green (2003), and Social Investment Forum (2001)). At the same time, investment managers have developed in-house quantitative risk models in order to be more precise and consistent in the evaluation of investment opportunities. These models are also used to provide more information to end-clients about the fundamental strategies employed by the managers. Our paper investigates the extent to which a variety of investors employ investment rules or risk models in deciding whether a country is investable.

In sum, our paper seeks to complement existing academic literature by documenting the practical internal decision-making processes used by international portfolio investors as well as uncovering the factors they indicate matter most in defining the investable universe. As such, this paper combines features of the three areas of academic literature mentioned above as it addresses issues in investment manager decision making, and the external and country specific factors which drive the investability decision. 


\section{EMERGING MARKET PORTFOLIO INVESTORS}

\subsection{THE UNIVERSE OF INVESTORS}

Emerging market investors are at the outset no different from investors in general. When we disregard bilateral and multilateral investors with explicit developmental objectives, the motives of international investors for investment into emerging markets are no different from the motives driving other investments: profitability and contribution to portfolio risk diversification. In broad terms, emerging market investors can be divided into the dedicated and the cross-over. ${ }^{1}$ Within these groups, they are as diverse in size and type as the emerging markets themselves, ranging from individual investors to large institutions to hedge funds of various kinds. However, the number of active investment managers in this asset class is small when compared to the number of actively managed portfolios investing in especially the U.S. debt and equity markets, and there appears to be a high concentration of assets under management in relatively few market players. ${ }^{2}$ We have found that the investability criteria vary rather systematically across general classifications of investor characteristics. In particular, the criteria can be differentiated according to the type of investment product they specialize in (equity or fixed income), the investment methodology (top-down or bottom-up) and the preferred currency (hard or local currency).

The most basic distinction we have observed is between portfolio investors looking at equity exposure and fixed income exposure. This first distinction mirrors the common way global investors take high-level asset allocation decisions by first dividing funds between equity, fixed income and cash, and then allocating each sub-component to different sectors and asset classes. Some of both the housekeeping and plumbing factors impacting the investability of a country are common to both equity and fixed income investments. These are typically high level factors assessing the overall political and economic environment or those determining whether a country is on the "cannot invest" list. As noted below, other factors have a more specific impact depending on the type of investment, i.e., whether debt or equity, whether sovereign or corporate. There is a tendency for equity investors to have a more elaborate set of minimum requirements for investments, especially within the plumbing category, than fixed income investors. This is not surprising as equity investors are, in general, more exposed to the quality of domestic financial systems and infrastructure than fixed income investors, as only a limited set of companies have equity products (such as cross listings, ADR's or GDR's), which trade and settle outside the local markets. However, as fixed income investors go down the credit curve from government to corporate credits and from hard into local currency this distinction gets less pronounced.

The type of investment methodology used by investors can also determine the key investability

\footnotetext{
${ }^{1}$ Cross-over investors are investors without a pre-commitment to invest in any particular asset class. Their investments are often only constrained by minimum rating requirements, and their movement into emerging market assets is opportunistic in nature. Cross-over investors typically invest in the higher grade emerging market countries and assets, and are most often absent from the asset class during periods of crisis.

${ }^{2}$ See Nelson's directory of investment managers for a description of US investment managers.
} 
criteria; in particular, whether the investor follows a top-down or bottom-up investment strategy. Most of the equity investors in our sample tend to follow a bottom-up strategy. In this case, a team of analysts typically uses company data to calculate various accounting ratios and make projections on earnings, and to ultimately highlight those shares that look cheap or expensive. The investability issue arises either before the process is initiated, where the investment team decides whether to include company data from a particular country, or it is discussed after a short list of potentially profitable companies is created. In the latter case, the managers take a closer look at the company to see if it falls short in implementing minimum standards.

For the top-down investor, by definition the analysis of the country comes first in the process. Depending on the characteristics of the business, the decision of whether a country is on the feasible list can be prompted by a specific potential transaction, or can be taken before transactions are considered as part of the management of overall country risk exposure for the firm. For example, many emerging market investments are undertaken by investment managers who are part of a larger firm (or bank) that wants to be aware of and control aggregate, country level exposures. In this case, the firm's risk department and/or risk committee decides whether the firm as a whole will invest in the country, and if so, the maximum amount of monetary exposure. Subsequent decision-making occurs after this "top-level" process. However, even in such an environment specific transactions may prompt changes in firm wide policies as individual managers ask for new or expanded lines to accommodate those specific transactions. For institutional topdown investors, which include dedicated emerging market investment funds, insurance companies and pension funds, the analysis of whether a country is investable is a by-product of the overall macroeconomic and political analysis of the country, which ultimately results in the identification of a number of investable countries based on the individual country scores achieved.

The last distinction which differentiates the investability criteria is between investments in hard or local currency. As we detail later, the most fundamental factors on the investability decision, especially for "may invest" countries, are related to the added complexity and insecurity of transacting and registering ownership in a local market, which is typically a necessity for all local currency investors, whether debt or equity. Hence, local currency investors will try to take this complexity into account in advance of doing any bottom-up analysis. Furthermore, the ability of investors to hedge currency exposure does have some impact on the investability decisions, for example through access to a non-deliverable forward (NDF) market or a functioning currency forwards or futures market. ${ }^{3}$ Here again local currency investors will stress different factors than hard currency investors in creating the feasible set of countries for allocation.

\footnotetext{
${ }^{3}$ Non-deliverable forward (NDF) contracts are instruments traded in foreign exchange markets. In an NDF contract, two parties agree on the future level of a currency cross on a specific date. On the agreed future date, the difference between the prevailing and contracted rate is settled in U.S. dollars; no local currency changes hands. NDF contracts were created for Latin American currencies in connection with the 1995 "Tequila crisis" but have subsequently become widespread. In these transactions, counterparty risk becomes a large issue, as well as the ability to establish a non-manipulatable reference exchange rate.
} 


\subsection{SAMPLE CHARACTERISTICS}

The documentation for this study was obtained through interviews with different functions (asset managers, risk managers, back-office) within selected institutions from the emerging market investor universe as described above. Over 30 interviews were conducted in the U.K. and the U.S. The sample included pension funds, asset management firms, hedge funds as well as commercial banks, including custodian banks or affiliates.

The dedicated emerging market assets under management by the different asset managers at the times of the interviews was approximately USD $\$ 15$ billion with a maximum but very volatile additional USD $\$ 5$ billion provided in form of cross-over funds. Most of the portfolio managers interviewed indicated that their assets under management had shrunk significantly from a pre1998 (Russia crisis) high, and that since the crisis, the proportion of dedicated emerging market mandates had fallen while cross-over assets had been growing.

While both equity and debt managers were interviewed, covering both local and hard currency investors, the dominant characteristic in the sample is one of a large asset manager managing third party funds with a fixed income mandate in hard currency. Most had long-only positions and strategic rather than "flipper" investment strategies; but some highly leveraged institutions (more often referred to as hedge funds) with short-term strategies were included in the sample nonetheless. ${ }^{4}$ No specific method was used to pre-select or pre-screen the institutions or persons interviewed.

A standard set of questions were used for the interviews with some adaptation according to the specific type of function or institution covered. In general all interviews extracted information about the size, mandates and types of funds under management, governance arrangements, type of investment model employed, as well as the existence of an implicit or explicit non-investable list of countries.

To supplement the information obtained from the sample, research of publicly available investment methodologies was conducted including information from the California Public Employees' Retirement System (CalPERS) and socially responsible investments from such sources as the Social Investment Forum in Europe, the U.S. and the U.K.

\footnotetext{
${ }^{4}$ The asset management/investment banking industry is over laden with buzzwords, some of which have squeezed their way into this paper (an example being "flipper" investment strategies). This term was originally used to describe short-term investors or day traders participating in IPO's with the aim of swiftly selling their holdings into the market days or even hours after first acquiring the stock. Here it is more generally used to describe investors with a very short term view to rapidly buy and sell an asset - or "flip" an investment - often in connection with a new issue or major announcements. One dictionary of acronyms and buzzwords can be found at: www.investopedia.com/dictionary/.
} 


\section{INVESTMENT METHODOLOGY}

\subsection{THE RIGOROUSNESS OF INVESTMENT GUIDELINES}

Given the wide variety of investors and types of funds that invest in emerging market assets, it is unsurprising that the methodology and processes vary. For example, the methodology used to create a list of investable countries has different shapes and attention to detail, tends to be particular to the investor type, and is most often a mix of precise number crunching and a heavy dose of intuition and subjectivity. As mentioned in the previous section, for a bottom-up equity fund, analysis of specific company characteristics comes before an assessment of the worthiness (or risk) of the country, while for a top-down external debt fund the country choice is the critical first step of the investment process. In either case, a sub-set of countries to analyze is usually created first. In addition, the decision as to which countries are among the feasible set of investments can ultimately rest with an end investor who provides specific guidelines, a risk committee setting country risk limits, a portfolio manager, or even with the trader of a hedge fund.

The degree of decentralization of the decision process and the ensuing degree of discretion left to the asset manager vary widely. Only recently have institutional investors such as pension funds started developing more rigorous investment guidelines for internal as well as external portfolio managers. One of the most rigorous publicly available investment guidelines has been developed by CalPERS. The CalPERS methodology uses a quantitative model with data input from external sources, in areas such as human and labor rights, to define a list of investable countries, see box 1 .

\section{Box 1: CalPERS investment guidelines}

Since it first started investing in international equity markets, CalPERS has only invested in those that met a number of explicit minimum investability criteria. Since 1989, CalPERS has relied on a consultant service - Wilshire Associates - to conduct and present to the investment committee a permissible market analysis. The methodology has undergone major revisions since 1999 dividing emerging market risk into two broad categories encompassing "market" and "country" factors. The categories of factors used to evaluate investment risk in 2003 included: political stability, transparency, and productive labor practices (country factors) and market liquidity/volatility, market regulation/legal system/investor protection, capital market openness and settlement proficiency/transaction cost (market factors). Based on an assessment of the individual factors, each country is given an aggregate score from 1 to 3 with the explicit goal of producing a relative ranking of each country's ability to support institutional investments. Appendix 1 provides more detail about the sources of information, sub-factors and the weights used to determine the actual country scoring. In 2003, Wilshire analyzed 27 countries on behalf of CalPERS, of which 15 were accepted for the permissible equity markets list. The 15 countries were South Korea, Poland, Israel, Czech Republic, Hungary, Taiwan, South Africa, Chile, Mexico, Jordan, Peru, Argentina, Turkey, Brazil, and the Philippines. The CalPERS investability criteria in reality affects not only the list of approved markets, but also companies within those markets, therefore bringing the very different top-down and bottom-up investment approaches closer together from the start. For example, Dimensional, one of CalPERS 3 active emerging market external fund managers, indicates that the initial universe of companies in investable countries in June 2003 was 359 . However, 77 of these were excluded from the potential "buy list" due to their individual failure to comply with the overall investability criteria. The second external manager, Genesis, indicated that they had reviewed 521 individual companies in 13 emerging markets and "failed" 47 of those due to their inability to comply with overall "investability" criteria. 
The CalPERS approach is an example of investability definitions at one end of the extreme insofar as attractiveness does not (in theory) affect the investability of a country at all. Most investment guidelines allow for some feedback from current investment opportunities into the list of investable countries. In other words, should an attractive investment opportunity arise for a country "outside" the list, this is in many cases ground for revision of the list, even if at the outset it is based on criteria unrelated to profitability. Cross-over investors often very simply limit the investable list of countries by credit quality, setting a minimum rating which has to be fulfilled before investments can be made in any country and/or type of security. At the other end of the extreme are funds that have no limits, that can invest in or short everything without restrictions. These are typically funds (such as hedge funds) where a lot of discretion is left to the individual fund manager. But even these kinds of managers usually operate with a list of investable countries based on market liquidity considerations and access to leverage the investments. Of course these funds will not invest in countries under international investment embargo leaving even this extreme end of the spectrum with a list, albeit wide, of investable countries.

\subsection{THE ROLE OF DATA AND MODELS FOR INVESTMENT DECISIONS}

At the beginning of the analytical process of creating an investable set of countries, investors canvass all countries that have 1) actual or potential assets to invest in and 2) available economic data. At a minimum, they create a standard data sheet that gives an overall macroeconomic picture of each candidate country, and at the extreme, feed the data into a specific statistical model to produce a country risk scoring system. Hence, one of the first basic criteria determining whether a country can make the investable list is whether there exist regularly published, quality data for the model's key variables. A non-trivial number of countries were excluded by nearly all of our sample's investors because of a lack of comprehensive data, an inadequate time series, or due to a lack of faith in the accuracy of published figures. In addition, many investors required data availability from a non-government source (EIU, IIF, etc.), for further verification before analyzing a country.

The use of a statistical ranking model in the investment decision-making methodology has grown with the trend toward greater global data dissemination, which in turn has been fostered by both investor demand (especially after a few emerging market crises) and the issuance of the IMF standards for data dissemination. While the models clearly differ among different investors, they all share basic similarities. First, the models all rely on macroeconomic variables to paint a broad picture of the stability and economic growth path of the country. These often include GDP growth, inflation figures (level and change), current account and fiscal deficit, as a share of GDP, and the major debt ratios (external debt/GDP and debt service as a share of exports). Second, many models include variables that attempt to describe the liquidity situation of the country, in terms of the monetary system and interest rate indicators (real interest rates, M2/GDP, etc.). Finally, and most important to local currency investors, the models incorporate variables which proxy for currency devaluation risk. These can include real exchange rate valuations, dummy variables representing an exchange rate regime, and international reserve data. Furthermore, many of these variables are used in papers seeking to identify the indicators or predictability of crises, see Kaminsky and Reinhart (1999) and Ades, Masih and Tenengauzer (1998). 
In general, many of these variables are relatively stable over time, and paint a fairly static picture of the overall macroeconomic stability of the country. For many emerging markets, the publication of much of this data is on a quarterly or annual basis, and is produced often with a substantial lag (the variance in data quality and publication speed is large). For those countries that have readily available market data (price related data such as interest rates), the picture can be refined more accurately.

While these macroeconomic variables form a crucial part of the ranking system for assessing country risk, most of the investors stress the more subjective criteria (more difficult to quantify) in their models. For example, political stability is considered a critical variable in the models, though it is difficult to assign a numerical value to quantify it. There is some outsourcing of the data inputs for these kinds of variables, ${ }^{5}$ but often the investment team creates its own scale and assigns values to each country. Other subjective criteria used in the framework include human rights variables, some indicator of corporate governance, and forecasts of economic performance in the coming years.

The method of aggregating the variables to create an overall score creates discrepancy among different model types. Rather than introduce another level of subjectivity, some of the investors merely equally weigh all inputs to create a relative ranking score. On the contrary, others weigh more heavily the variables they deem most important; most often these are the forward-looking indicators.

At the end of the process, each country has a risk ranking score. In most cases, this score serves as a first check for whether the fund should be in the country. However, the score is more often used to contrast with a valuation measure for either equities or bonds in order to judge whether a country (or investment) is attractive on a risk/reward basis. Though all investors who use these models assert that the risk score is an integral part of the investability decision, it is not decisive. The investor always has the ability to overrule the results based on his/her own subjective opinion of the quality of the investing story.

Generically speaking, the investment process as it relates to country choice can therefore be summarized for most investors in our group as a four-stage process. First, data is gathered and put into general macroeconomic fact sheets, and in most cases, crunched through an econometric model to produce a country risk score. Thanks to the recent quantification of many subjective indicators relating to such areas as political and labor issues, these criteria can often be included in the statistical analysis. Second, the country scores are compared by the investment committee

\footnotetext{
${ }^{5}$ For example through specialized consultants, such as Political Risk Services, Wilshire Associates, KLD Research \& Analytics, etc.; through use of specialized information providers such as, the Economists Intelligence Unit (EIU), Business Monitor International, Freedom House, ILO, the Global Corporate Governance Forum, Transparency International, the World Bank and the IMF; or to the rating industry which has started corporate governance ratings. An increasing number of independent firms are creating indices of political stability, corruption, and human rights, which were incorporated into almost every quantitative risk-scoring model to which we were exposed. The steadily increasing number of consultants and data providers covering these specialized topics shows the increased importance investors and policy makers place on adherence to a wide range of global standards.
} 
(which could be a risk officer, fund manager, etc) and some countries are eliminated at this stage due to their risk. Third, the ranking is compared to external sources of risk rankings, whether they are credit risk ratings or EIU ratings, for example, in order to pick up outliers or major differences between the committee's intuition and the raw statistical numbers. In some cases, the risk scores are adjusted at this point subjectively. Fourth, the committee and/or managers compare the risk to expected reward measures, and ascertain the countries to which they will allocate funds. In essence, the feasible set of countries includes any of those that appear in the risk/reward analysis. The above analysis holds most true for the top-down investors. For the bottom-up, the country selection process typically ends at the country risk scoring level, where countries are ruled out based on risk, as afterwards it is the company and/or industry specific information that drives the decision. Some funds must of course eliminate countries from the list according to specific client mandates, whether pertaining to risk factors or issues such as human rights.

Figure 1: Hypothetical Risk / Reward Tradeoff

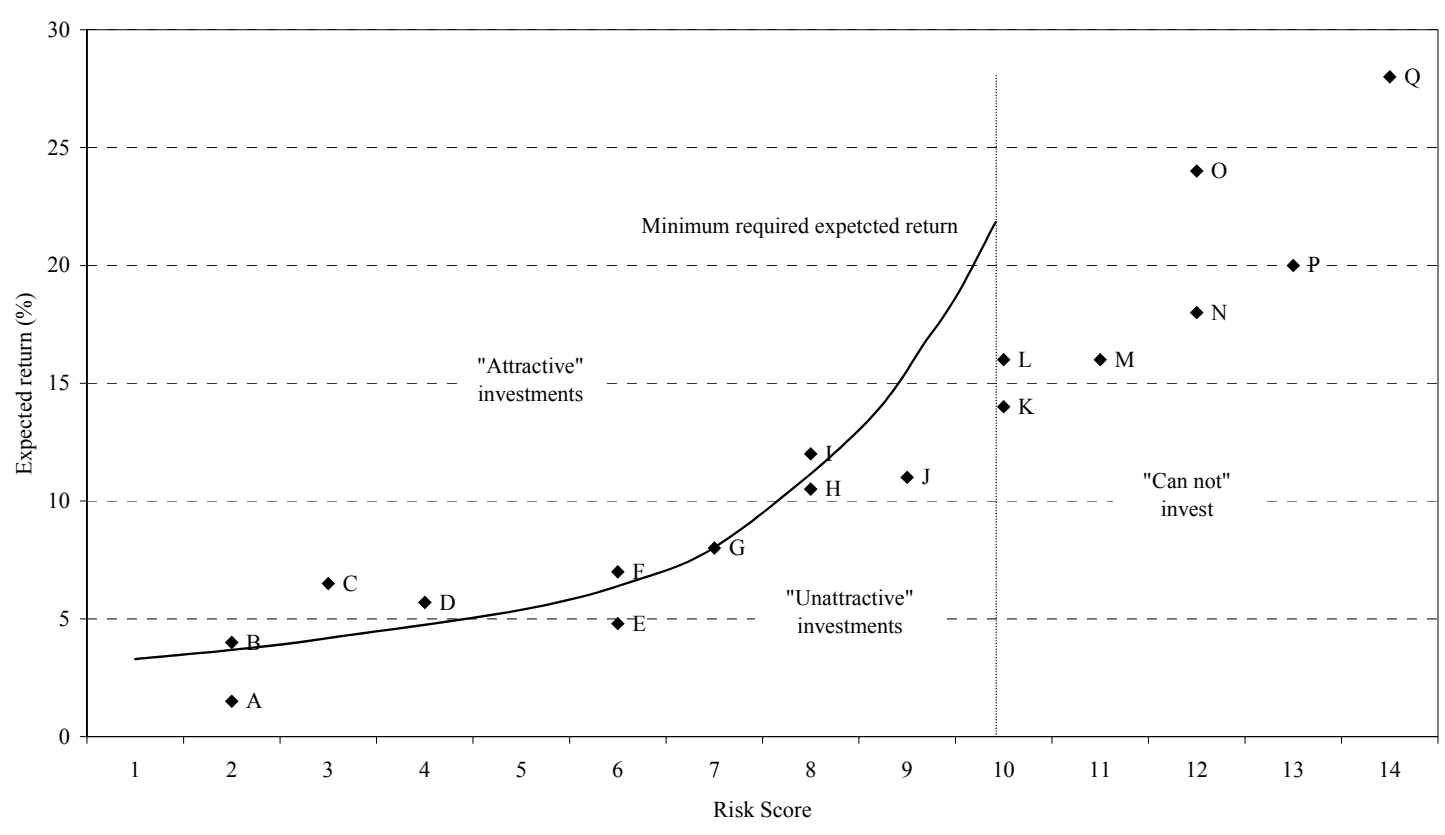

Very often the models result in a convex risk versus required expected reward relationship where there will be discrete jumps in the curve as a consequence of large jumps in the required expected returns for the same changes in credit quality at the low end of the credit scale. Figure 1 shows a stylized and hypothetical outcome of the risk/reward number crunching process. In this hypothetical case the investor utilizes a model that score investments on a scale from 1 to 14 with lower numbers indicating lower risks. For investments with a risk score of 1 to 6 there is a marginal but increasing required reward for a given level of risk. However, the large subsequent increase in "required reward" (which can be considered a bond yield, for example) illustrates a type of kink in the risk/reward tradeoff. From the investor point of view, the investability decision could entail writing off any country with risk higher than 10 (in the above example) from the feasible set. No matter the additional reward, the risk is too high. From the country's per- 
spective, this kink also illustrates that small improvements in its risk assessment may result in big reductions in the expected required returns, and as a result, a substantial reduction in financing costs. Even more importantly, it shows that especially for countries that score low in the investability analysis (high risk), even small improvements may have large effects on the access to capital even in situations where the ranking is mainly a result of the macro (monetary/exchange rate and fiscal policy) stance.

The minimum required expected return curve divides the universe of investments into "attractive" and "unattractive" investments depending on whether the actual investment is expected to yield more or less than the minimum required expected return. While the model represents a crucial core of the investability decision, in all of the cases we interviewed, the data or model output alone did not decisively put a country on or off the investable list or in the "attractive" or "unattractive" category. After the model process, each could use subjective criteria (i.e., interpretation, the search for a story that overrides the data, etc.) to either rule out a country or overlook a bad score.

\section{5 "MUST" INVEST COUNTRIES}

Benchmark indices for both equity and debt have significant explicit and implicit effects on whether an institutional investor will consider investments in a country. ${ }^{6}$ Many funds that recruit client money are marketed as benchmarked to an index, which obliges the fund manager to hold the majority of the assets in the countries of the index, with small deviations allowed for cash management and some active decision-making. ${ }^{7}$ According to the MSCI website, over $90 \%$ of U.S. institutional assets held in international equities are benchmarked to the MSCI indices. ${ }^{8}$ For these stricter funds, a large part of the investor's investability decision is not a matter of choice but rather a function of whether a country has enough debt to warrant inclusion in an index. Perversely, this characteristic of benchmarked funds thus rewards countries with a large quantity of

${ }^{6}$ A number of daily updated emerging market indexes are available: EMBI, EMBI+, and EMBI Global from J.P. Morgan Chase, Brady Bond Index from Salomon Brothers, Morgan Stanley Capital International (MSCI) and emerging Market indexes from Merrill Lynch and Lehman Brothers.

${ }^{7}$ Normally, few indexing strategies can perfectly match the performance of the index or benchmark. The tracking error quantifies the degree to which the strategy differed from the index or benchmark. Tracking error can be defined in different ways, the most common being either as the variance (standard deviation) of the difference between benchmark returns and returns on the replicating portfolio (see for example Pope and Yadav (1994)), or as the difference between portfolio returns and benchmark returns (see for example Roll (1992)). The latter is the most common definition used by market practitioners.

${ }^{8}$ A new strategy in asset management is becoming increasingly popular in both Europe and the U.S. among institutional investors. Instead of making choosing between either active or passive management a strategy is employed where the major part of the assets is invested in a "core" benchmark driven portfolio with low management fees and low allowed tracking error, while a small share of the assets is invested in "satellites" where managers can invest freely. This "core/satellite" approach lowers cost as the higher fees associated with active management of the portfolio are only paid for the part of the portfolio, which is truly actively managed. 
debt with a captive class of investors, even though high debt ratios would normally reduce an investor's appetite for the country's debt.

Even if a fund is not specifically benchmarked to an index, investment of funds received through institutional mandates may be constrained both by risk-tolerance limits (defined in such terms as limits on investments in certain types of assets, diversification rules, minimum allowed rating of investable securities, maximum tracking error from an index) and through the performance criteria for evaluating management. In almost all cases, a good part of a fund managers compensation is based on the fund's performance relative to a benchmark index. Consequently, the manager cannot afford to take substantial off-index country bets (i.e., create too much tracking error), as she risks her own compensation or retraction of the mandate if events go awry, even if they are not related to her active portfolio management. While it does not rule out specific non-index countries, performance evaluation relative to benchmark performance does limit the amount of funds available to non-index countries.

The problems associated with benchmarking are well known, and have gained renewed scrutiny since the Argentine default. ${ }^{9}$ In the early to mid-1990s international investors invested heavily in Argentina, rewarding the country for the implementation of economic reforms. By 2000, the government had built up a large debt stock, so that Argentina represented one of the largest country components in all emerging market debt indices. As the macroeconomic and political climate soured, and questions surfaced regarding the sustainability of the debt profile, investors steadily reduced their holdings of Argentine debt. However, Argentina's large weight in the indices forced many managers to maintain some holdings. According to an article in the Washington Post, several money managers admitted "The index virtually forced big investors to lend vast sums to Argentina even if they feared that the country was likely to default in the long run,..."10. Although default would hurt absolute performance, the fund would still lose less than the index as long as the fund was underweight Argentine bonds.

The distribution of countries in terms of weights in various emerging market benchmark indices is shown in table 1, below. The EMBI indices are emerging market global hard currency bond indices calculated by JP Morgan Chase. The ELMI is an emerging market global local currency index also calculated by JP Morgan Chase, and the MSCI (Emerging Markets Free) and Standard \& Poor's (global composite) indices are both emerging market equity indices produced by Morgan Stanley and Standard \& Poor's. Those countries that show up in the last two columns, for weights in indices of over 5\%, typically "must" be included in institutional investors' portfolios, for reasons specified above. For those countries in the $0-5 \%$ category, investment managers

\footnotetext{
${ }^{9}$ The BIS Committee on the Global financial System (CGFS) has recently examined the implications of the increased use of indexing for financial markets in connection with the work of an ad hoc Working Group on Incentive Structures in Institutional Asset Management. See BIS (2003a).

${ }^{10}$ Paul Blustein. The Washington Post. Aug 3, 2003. Argentina Didn't Fall on Its Own; Wall Street Pushed Debt Till the Last.
} 
have some discretion. ${ }^{11}$ In this sense, the investor's own investability criteria can come into play on whether to include these countries, on the margin. Again, there is a trade-off between tracking error relative to the index and the desire to beat the index, which by definition means varying the weights each country represents in the portfolio.

\section{Table 1: Number of countries by weight in key emerging market indices}

\begin{tabular}{l|c|c|c|}
\hline & \multicolumn{3}{c|}{ Weight (\%) } \\
\cline { 2 - 4 } & $0-5$ & $5-10$ & 3 \\
\hline EMBI Global & 28 & 0 & 2 \\
EMBI Global diversified & 23 & 6 & 0 \\
ELMI+ & 16 & 8 & 3 \\
MSCI & 19 & 4 & 2 \\
S\&P/IFC composite & 24 & 7 & 3 \\
\hline
\end{tabular}

Note: The specific country weights are confidential information for most indices.

Source: JP Morgan Chase, Morgan Stanley, and IFC.

In sum, the benchmarking of investment funds, either directly or indirectly, can impact the investability decision of managers by placing a country either in a "must" invest category or a "may" invest category, the latter offering a degree of discretion for investment. However, just because a country is not in an index does not preclude it from the investable universe; rather the appropriate "housekeeping" or "plumbing" issues then come into play to make an investor use his deviations from benchmark to invest in it.

\section{6 “CANNOT" INVEST COUNTRIES}

As mentioned in the introduction, only a few countries are found to be explicitly or implicitly on the "cannot invest" list. The main criteria defining this set of "blacklisted" countries are related to the country's standing in the international community, the quality of its plumbing / infrastructure, or criteria specified by clients. Consequently, the "cannot" list or the "non-investable" list comprises countries where either the end investor or the asset manager in practice has lost the discretion to invest.

\footnotetext{
${ }^{11}$ All the emerging market indices mentioned have a number of minimum criteria which need to be fulfilled even before an issue from a country is included in the benchmark; completing an international bond issue is by no means a guarantee of inclusion even with a small weight. For smaller countries, emerging and developed alike, the minimum criteria may be insurmountable: e.g., a minimum individual size of a series (for some, around US\$250 million); specific types of fixed instruments only; and minimum total outstanding marketable debt. Such requirements will be impossible for many small countries to fulfill.
} 


\section{Box 2: International Sanctions}

United Nations: The UN Security Council may call upon Member States to apply sanctions “ “. . in order to maintain or restore international peace and security." This possibility in the United Nations charter has been invoked through the history of the UN 14 times. In the cases of Angola, Ethiopia and Eritrea, Haiti, Libya, South Africa, Southern Rhodesia, Sudan and the former Yugoslavia, sanctions have been fully lifted. In the case of Iraq, sanctions have been lifted, with the exception of some prohibitions related to the sale or supply to Iraq of arms and related material. Currently various sanctions are imposed against the Taliban in Afghanistan, Liberia, Rwanda, Sierra Leone, and Somalia. The sanctions applied through the UN Security Council have most commonly taken the form of arms embargoes while broad based economic sanctions have been relatively rare. Sanctions limiting international capital flows were applied in the cases of the former Yugoslavia and most recently Iraq. For an updated list of countries affected by UN sanctions and the specific Security Council resolutions see:

http://www.un.org/News/ossg/sanction.htm.

United States: The U.S. has sanctions and embargoes against both certain countries and specific activities. The U.S. Treasury Department's Office of Foreign Assets Control (OFAC) administers the sanctions and embargo programs. Currently country specific sanctions are in place involving Libya, Iran, Sudan, Cuba, Syria and North Korea. Furthermore, a number of prohibitions have been put in place including: dealing with foreign persons who promote the proliferation of weapons of mass destruction; importing rough diamonds from Sierra Leone and Liberia; transacting with designated terrorists and terrorist organizations, international narcotics traffickers, parties named in the Balkans, and parties named in Zimbabwe, etc. Securities firms are prohibited from dealing in securities issued from target countries and governments and must block or freeze accounts, assets, and obligations of an extensive number of blocked entities and individuals located in cities all over the globe. For a current list of sanctions and embargos see: http://www.ustreas.gov/offices/enforcement/ofac/sanctions/index.html.

The most universal action that puts a country on this list is related to foreign policy sanctions. In practice, U.S. foreign policy is more important than other individual country policies or even that of the UN. While countries affected by UN sanctions can be blocked from legitimate international portfolio capital flows, the UN sanctions only rarely involve explicit limits on financial interaction (see Box 2: above). In theory, U.S. sanctions and law only apply to U.S. investors. However, due to the importance of the U.S. for the international financial system, and of U.S. investors/asset managers for emerging market flows, countries affected by U.S. sanctions are also almost automatically on the "cannot" invest list for the vast majority of investment managers. Consequently, any firm that operates under U.S. law cannot invest in countries such as Iran, Libya, Cuba, and until recently, Iraq. Furthermore, no U.S. investment bank is allowed to transact (settle, clear or take custody) of any security originating from these countries, which in practice makes it nearly impossible for even non-U.S. investment funds to participate due to the dominance of U.S. firms in the international trading and custody business.

Changes in the general policy stance of the U.S. toward a country may also affect a country in more subtle ways. Recently Guatemala postponed issuance of an international bond after being removed from a U.S. list of nations cooperating with efforts to curb narcotics trade. This prompted the leading underwriters Deutsche Bank AG and Morgan Stanley to pull out of the 
transaction. Guatemala some months later tapped the market with the help of a new leading (non-U.S.) underwriter. ${ }^{12}$

In terms of the implicit "cannot" list, plumbing attributes such as the safekeeping of assets and the registration of ownership can effectively bar a country. This impact is mainly felt for local currency investments. While the main international custodian banks over time have opened the vast majority of markets to international investments, there are still countries where international custodial services are not available. This may be because no interest has been shown from investors for the custodians to seek to open the countries, but, in a few cases, has to do with deficiencies in the plumbing. The minimum requirements set by the custodian banks before a country is considered investable from the custodians point of view are very basic. In general red flags are raised if a country does not legally recognize the concept of a sub-custodian; if the sub-custodian cannot represent the owner's interest (absence of a legally recognized nominee concept allowing a third party to act on behalf of the final owner when it comes to e.g., corporate actions and proxy voting); if there is uncertainty about the finality of registration of ownership; if a process for control of assets is lacking; and/or if there is a lack of separation between client and proprietary assets at the level of the sub-custodian or broker.

Another segment of the "cannot" invest countries are defined through discretionary decisions made by the endinvestors. Much media attention has been given recently to the growing importance of "socially responsible" investing, for example. Advocates suggest that certain countries be blacklisted due to negligence in enforcing human rights, labor laws, etc., see Box 3: below. However, our investor sample only included one very small fund with specific criteria defining a set of non-investable countries according to their compliance with a set of "social" criteria. These "social" criteria may include social, environmental and ethical issues, encompassing topics such as human rights, labor laws, labor rights, corruption, and rule of law in general. These factors are all subjective in nature, but do form a part of whether a country is included on the investable list. The factors appear prominently both in the models and in forming the subjective opinions of the investors when at the margin they consider whether to invest in a country.

As mentioned above in section 3.2, lack of data, or problems with data quality, length of history and timely release, may also put countries on a non-investable list. ${ }^{13}$ Many investors prefer data from independent sources, but this is not normally required. It should be noted, however, that some of the investors we interviewed actually preferred opaque environments; these were typically small (hedge) funds spending a lot of time investigating nascent markets, seeking out information from direct contact with counterparts in the countries under investigation.

\footnotetext{
12 Bloomberg, July 29.

${ }^{13}$ Gelos and Wei (2003)
} 


\section{Box 3: "Socially Responsible" Investment}

The term socially responsible investment is not particularly well defined as it may cover a number of issues related to social, environmental as well as ethical standards. Some organizations use "ethical investments" to describe investments based on the exclusion of certain stocks ("negative screening"), for example those of tobacco and arms companies or firms using child labor. "Socially responsible investments" or just "responsible investments" may involve both the exclusion of certain stocks - or markets - not living up to the required minimum standards or the positive selection of companies who are social, environmental or ethical leaders within their industry. These could for example be companies adhering to the Global Sullivan Principles of Social Responsibility (http://globalsullivanprinciples.org/).

According to the Social Investment Forum in the U.S.: "Socially concerned investors generally seek to own profitable companies with respectable employee relations, strong records of community involvement, excellent environmental impact policies and practices, respect for human rights around the world, and safe and useful products." (http://www.socialinvest.org/). "Socially responsible" investors may, apart from investing, disinvesting or withholding investments, try and influence companies to follow and adhere to specific standards by direct dialog with company management as well as shareholder proposals and voting at general meetings. In the U.S. the Shareholder Action Network seeks to strengthen shareholder advocacy by bringing investors with a socially responsible investment perspective together (http://www.shareholderaction.org/).

While no one particular organization has a monopoly on defining socially responsible investment practices, or for that matter, assessing compliance, a number of independent regional and national Social Investment Forums (SIF's) have sponsored or directly worked on these issues. They include: European Sustainable and Responsible Investment Forum (Eurosif) (www.eurosif.org); U.K. Social Investment Forum (www.uksif.org), Association for Sustainable \& Responsible Investment in Asia (ASrIA) (www.asria.org); Australian Ethical Investment Association (EIA) (www.eia.org.au); Canadian Social Investment Organisation (SIO) (www.socialinvestment.ca); and U.S. Social Investment Forum (SIF) (www.socialinvest.org)

\section{7 "MAY" INVEST COUNTRIES}

The largest group of countries falls in the "may invest" category, where investor discretion is the highest. Countries falling in the "may invest" category are those which at the margin have the most opportunity to increase their likelihood of becoming investable, or increasing their investability. This section describes the most important factors which influence investability: housekeeping, plumbing, and size of issue, investor, and country.

\subsection{HOUSEKEEPING}

\subsubsection{Macroeconomic conditions}

Unsurprisingly, the macroeconomic factors that contribute to the stability of the economy rank perhaps the highest in importance to investors in terms of determining whether a country is investable. Whether the investments are in debt or equity, by large asset managers or small hedge funds, the priority for all investors is the joint assessment of the growth potential and probability of a crisis which can derail the country from the growth path. Clearly, inflation, the trade and current account, the fiscal balance, the exchange rate regime and path, and the general make-up of the economy in terms of industrial base and natural resources are all obvious characteristics 
that investors monitor, and form the first hurdle the country must pass in order to be put on the feasible list.

Within the realm of macroeconomic stability, but perhaps the second most important variable investors paid credence to after growth forecasts, is the country's ability and method of financing its current account deficit. It is taken as a given that emerging markets have current account deficits. However, if the country is relying on what is considered as the more volatile and fickle portfolio flows to finance the deficit, rather than foreign direct investment (FDI), investors attach a much higher risk to the country. Again, in times of volatility or crisis, portfolio flows can be withdrawn rather rapidly while FDI is in the country for the longer haul.

The sovereign ratings set by the international rating agencies do factor into the models, but in our sample, rarely directly. While some investment mandates will restrict investments into countries with ratings below a certain level (typically below investment grade) the impact through the models is more indirect. The external ratings - or rather the relative ranking of countries - are instead used as an external reality check on the results of the proprietary models. Large divergence between the results of the macro part of the in-house model and the external ratings will result in a more thorough investigation as to why the differences occur, but by no means necessitate a change in the in-house rating. Having a country's sovereign rating also helps in so far as the rating agencies provide readily available periodic coverage of the economic situation and collect macro-economic data, which can be fed into the models.

\subsubsection{Political environment/stability}

The political environment of a country also plays a very important role in whether an investor deems that country investable. While it is difficult to describe one characteristic that adequately summarizes what is meant by political stability, in a broad sense investors look for transparency and predictability in how a country's government changes through time. Whether a democracy or a totalitarian regime, if a country has an established process for political change, the direction of future policy and leadership becomes more understandable, and investors are much more comfortable with assessing probabilities of economic growth and the country's intention to pay its debts. Where the macro factors are used to assess a country's "ability to pay" its debt obligations, the analysis of the stability of the political environment traditionally is used to assess its "willingness to pay". An obvious risk is related to a change in administration, where a new administration does not feel obligated to honor the commitments made by a previous administration that it feels lacks legitimacy.

\subsubsection{Quality of local financial markets}

While the quality of local financial markets - apart from aspects related to the quality of the "plumbing," which we cover in section 7.2 below - did not surface immediately as an important indicator of whether an investor would consider investing in a country, several aspects emerged throughout the discussions which made this feature quite prominent anyway. The main aspects 
were related to the stability of the local financial system, especially the banking system, and the depth and breadth of the local investor base.

Investors did pay credence to the stability of the local financial system at large, including the banking system and securities markets. A country with a banking crisis brewing would find itself off the investability list of many investors, due to the fear of repercussions in both value and the ability to move funds through the system. For this specific reason, equity and local currency fixed income investors tended to be more cognizant and wary of the health and characteristics of the financial systems, not only due to the more intrinsic relationship between the value of the exchange rate and the macroeconomic repercussions of an unstable financial system, cf. 7.1.1 above, but also due to the negative impact on the ability to transact in a market experiencing a crisis. ${ }^{14}$ In general, hard currency investments were less likely to suffer a significant, immediate impact from a local financial market crisis than local currency investments, so that this factor played a smaller role for many investors in our sample.

However, the depth and breadth of the local investor base turned out to play a prominent role in the investability decision for many reasons, for both hard and local currency investors. If there is a substantial local investor base, the government has a larger variety of funding alternatives than relying merely on external sources for funding deficits. Therefore, the country is less susceptible to external shocks which shut off capital flows, leaving it in a crisis where interest rates rise dramatically, and economic conditions worsen overall. Hence, funding risk is lower, and the perception of the country's investability is higher.

The local investor base was also important to many of the investors in our sample due to the information their actions provided. Even with today's technology, local investors tend to be more aware of local events, and more connected to the political environment, so that they are able to better ascertain the general level of risk and movements in value. As such, these local investors' behavior and research publications can give important signals to the external world. A few hedge funds prefer not having much information on a country as they use their own resources to investigate and attempt to exploit asymmetrical information. The majority of other investors find a local investor base (both in terms of brokers and other investors) to be a critical component in the early stages of the investability decision. As such, the quality of the local financial system is here linked to a data and information provision, rather than a stability issue.

Also improving a country's investability is the ability of foreign portfolio investors to use the local investor base as counterparts in secondary trading. While local intermediaries in many markets play an important role in creating liquidity for international investors, generally they are especially important in times of external market volatility, where global liquidity is tight. Many international investors rely on the local investor community as the "back-stop" liquidity facility

\footnotetext{
${ }^{14}$ Only few emerging markets allow for equity exposure unrelated to the quality of the domestic financial system. While ADR's/GDR's trading and settling in external markets are available for some companies, they only represent a fragment of the investment universe. Furthermore, exposure to general emerging market indexes is also limited, and even if available, often exposed to the same quality of the domestic financial system concerns.
} 
to buy their securities. For example, Brazilian investors have often bought Brazilian bonds from international investors during periods of perceived emerging market crises, whereas many other countries have very few investors interacting with the global market. While other factors clearly make Brazil investable, this feature can put marginal countries in the feasible set.

While the two positive effects of having a local financial market mentioned above are seemingly incongruous - how can local investors at the same time have an informational advantage and allow themselves be used as counterparts for international investors "dumping" investments in time of crisis - they are, in reality, not. Even with the same level of information, local and foreign investors may interpret the consequences of new information differently, they may have different risk preferences and tolerances, and, most importantly, may have very different abilities to act on their risk assessment. The political connection between local investors may be a doubleedged sword allowing for better information but also larger susceptibility to outside (indirect or direct) influence on investment decisions. From the foreign investors perspective, this is a clear benefit. In Argentina's case, for example, in mid-2001 the domestic private pension funds were used to postpone default, which in turn allowed more international investors to leave the market. ${ }^{15}$ Consequently, the characteristics of the local investor base will feature in the part of the investability analysis which concerns the ability of the country to finance its deficits. ${ }^{16}$

\subsubsection{Corporate governance}

The portfolio equity investors in our sample placed very high importance on the quality of corporate governance both at the level of the individual company and in terms of the overall minimum standards set at the country level. In some countries, with more than one public market, the difference in corporate governance standards set by the individual market may be large enough to make only those companies listed on some specific exchange (or sub-market) investable. ${ }^{17}$

\footnotetext{
${ }^{15}$ The funded part of the current Argentinean pension system dates back to 1994 with assets worth around $7.5 \%$ of GDP or USD 20 billion by end 2001. Federal and State Government bonds had from the outset accounted for around $50 \%$ of the assets, and bank deposits for another $20 \%$. By mid 2001 the fiscal crisis prompted a restructuring of the debt where primarily the domestic pension funds accepted a swap of short maturity debt for 10 to 30 year government bonds. Only very few, if any, foreign investors took part in the swap-operation, prompting the pension regulators to increase the prudential limits for how much government debt pension funds could hold. In December, 2001, the crisis had deepened even further and the government involuntarily converted the pension funds fixed term deposits in domestic banks to government bonds or government guaranteed loans. At the end of 2001 close to $80 \%$ of pension fund assets were composed of government bonds or guaranteed loans. For more see Rofman (2002).

${ }^{16}$ Research has shown a robust relationship between the development of the contractual savings industry and the securities market in general. More specifically securities markets with good quality corporate information and mandatory pension fund contributions benefit most from the development of a contractual savings industry, see Impavio, Musalem and Tressel.

${ }^{17}$ Some public markets have been set-up with the explicit aim of attracting companies complying with high corporate governance standards and investors willing to pay a premium for compliance with such standards. See for example the experience of the Novo Mercado in Brazil which was set up to create ".... a more propitious environment
} 
Corporate governance standards may cover a plethora of issues. The most widely used benchmark for good corporate governance - the OECD Principles of Corporate Governance - cover five main areas: I) rights of shareholders; II) equitable treatment of shareholders; III) role of shareholders in corporate governance; IV) disclosure and transparency; and V) responsibility of the board. One of the most important initiatives in this area is the World Bank and OECD Global Corporate Governance Forum. This forum brings together leading bodies engaged in worldwide governance reform: multilateral banks active in developing countries and transition economies, international organizations, and country groupings engaged in governance reform, alongside professional standards setting bodies, and the private sector. The Global Corporate Governance Forum seeks to broaden the dialogue on corporate governance, to exchange experience and good practices, and to coordinate activities and identify and fill gaps in provision of technical assistance. ${ }^{18}$

The investors in our sample singled out corporate governance practices which ensure transparency and good alignment of interests between management and (minority) shareholders as the most crucial for the primary investability decision. Investors in our sample use external datasuppliers as well as direct meetings with the companies to provide input into the assessment of the overall quality of a market's corporate governance practices. Specialized consultant companies and investment banks as well as international financial institutions all provide assessments of the overall quality of the corporate governance environment in emerging as well as developed markets. ${ }^{19}$ Rating the quality of corporate governance is, however, notoriously difficult without going to the firm level. While rules and regulations may require having, for example, independent directors on the board, the directors may be so friendly with the major shareholder that the intended independent check is only nominal. Many bottom-up equity investors, therefore, spend a good deal of time and effort assessing the quality of corporate governance in individual companies and, in some cases, countries.

Investors in our sample may leave out otherwise attractive companies from their investable universe due to lack of adherence to corporate governance standards (as in the case of investment managers employed by CalPERS cf. Box 1: above), but they will often continue to monitor these companies, and if the potential to create additional value is present, will use influence to exert pressure and change the corporate governance situation. Pressure is exerted either by individual institutional investors or through associations, etc. Corporate governance is one of the few areas where institutional investors especially have found enough common interest to overcome the diversity in investment strategy which otherwise keeps strong all-encompassing alliances from

for companies to afford investors a higher level of accountability through good corporate governance practices and greater transparency, and, as a consequence, reduce funding costs ", cf. www.bovespa.com.br.

${ }^{18}$ For more about the work of the Global Corporate Governance Forum see http://www.gcgf.org.

${ }^{19}$ See for example the work done by KLD Research \& Analytics, Credit Lyonnais Securities Asia (CLSA), and the summary assessments of the observance of selected standards and codes conducted by the World Bank and IMF, which, in some countries, include the OECD corporate governance principles, see http://www.worldbank.org/ifa/rosc.html. 


\section{Box 4: The Russell 20-20 Association}

The Russell 20-20 Association is a non-profit association formed in 1990 to influence transition countries by collectively bringing the viewpoints of foreign investors' to governments developing a regulatory framework and facilitating a commercially driven business climate for the first time. The focus has since been broadened to all major emerging markets, or indeed to any market (region or country) of interest to the members of the association. The Association members meet with high-level officials and business leaders in target countries providing a venue where international investors can express their views about the current investment environment to policymakers. The group uses its combined strength to gain access and influence policy setting in a more efficient way than they could as individual institutions. According to the association Russell 20-20 members represent institutions with a total of US\$ 7 trillion in investment assets. For more see http://www.russell.com/ww/About_Russell/r2020.asp

forming. (See Box 4: below for a description of one of the industry alliances: the Russell 20-20 Association). A recent study by Aggarwal, Klapper and Wysocky of the investment behavior of U.S. mutual funds also documents that at least U.S. mutual fund managers do vote with their feet when it comes to e.g., the quality of corporate governance.

\subsection{PLUMBING}

Factors related to the quality of plumbing in a particular market are mostly of concern to local currency, either in equity or debt, investors. While the factors described above all have a bearing on the quality in terms of market and credit risk of holding the investment asset, we classify plumbing factors as those that deal with risk, cost and quality of executing either acquisitions or sales of assets as well as maintaining registration of ownership and exercising ownership rights through the life of the investment.

A key part of the plumbing for foreign investors in local markets is related to the security and availability of the assets in which they have invested. Most portfolio investors use the custody services of the major international custodians, which again typically use a system of agent banks and depositories to provide the final services. In this context key failures leading to access limitations include: if there is a lack of recognition of the concept of a sub-custodian; if the subcustodian cannot represent the interest of the final owner and execute asset servicing in areas such as corporate action processing, income collection, proxy voting and taxes; if uncertainty exists around the finality of registration of ownership; if a process for control of assets is lacking; and/or if there is a lack of separation between client and proprietary assets at the level of the subcustodian or broker. These basic plumbing factors must be in place before foreign portfolio investors can be expected to enter into the market. However, most countries with active capital markets have already dealt with these basic plumbing issues, as witnessed by the long list of countries where the custodian banks have an indirect or direct presence. For example, State Street's custody services are available in more than 100 countries.

While failure to live up to the basic minimum requirements in most cases will result in a market being labeled "cannot invest," cf. section 6 above, relative adherence to these requirements may give a country a higher ranking in the "may invest" group. In addition, other less fundamental 
plumbing issues may be overcome through alternative solutions. These alternative solutions will, however, often add to the fixed costs involved in investing in a particular market. For example, foreign institutional investors use specialized subsidiaries set up in Mauritius to access the Indian securities markets, in order to avoid particular taxes. In other cases, asset managers have engaged in direct negotiations with authorities to use specialized country funds to access otherwise closed capital markets, and accepted restrictions on how and who to deal through in the local market to gain access and work around deficiencies in the local plumbing. Specifically, such country funds have been used to gain access to, for example, South Korea, India and South Africa. Consequently, getting the plumbing to work efficiently may be more important for smaller countries, as the benefits to scale may make investments there prohibitively expensive for some types of investors.

Many emerging markets have increasingly realized the importance of establishing a costefficient and robust securities settlement framework. It is telling that the "Permissible Equity Markets Investment Analysis and Recommendations" prepared by Wilshire Consulting for CalPERS in January 2003 singles out settlement proficiency as the area where the most significant improvements were made from the 2002 to the 2003 analysis. The emerging markets covered by the Wilshire analysis had all moved to electronic trade settlement and electronic depositories, with, mostly, three-day rolling settlement cycles. Interviews with the back office personnel of the investors indicated that securities settlement and registration of ownership are truly key elements of plumbing, which, if deficient, will leave local investments off the investability list.

Some of the softer aspects of the infrastructure, which are more commonly overlooked, may have similar consequences. Stamp duties and cost of ownership registration are two of those factors that may tip a market into an unattractive realm. Some investors in our sample estimated that stamp duties and registration costs amount to as much as $50 \%$ of their total transaction costs, e.g., in Russia. As these costs normally are variable, rather than making a country un-investable they typically will increase the minimum required pre-cost return and be fully factored into the demand schedule, thereby raising questions as to whether the net effect on government revenues is positive.

While the local regulatory structures also are of importance to the assessment of the quality of the housekeeping, they are also important from a plumbing point of view. Even if the main issues related to registration of ownership and execution of ownership rights have been dealt with in such a way as to put the country on the "may invest" list, if a country frequently changes the rules, or just as importantly changes their legal interpretation, direct and indirect transaction costs will increase, and may drive investments out of the country. Investors and providers of custodial services in our sample, especially pointed to problems related to ambiguous tax rules, erratic rule changes without adequate explanation and/or consultation as well as - from their point of view - excessive consequences of non-compliance (e.g., if settlement failure results in transaction suspension for a long time period, this may in itself keep investors from entering).

Other seemingly trivial practical issues can keep a country off the investable list. One of these factors is the usefulness of the English language in legal documents, either pertaining to the investment laws in general or merely the transaction contracts. Apparently for many years, all 
vestment laws in general or merely the transaction contracts. Apparently for many years, all Russian transactions were negotiated with Russian legal documents, which required international investors to employ a Russian-speaking lawyer to review. This made the transactions costly and cumbersome, and caused many investors to exclude such investments from the feasible set.

Another exclusionary example provided by one investor was due to currency units. Due to many years of high inflation, the Turkish lira exchange rate evolved to append several zeros. This investor was unable to handle such large units in the firm's systems, both for accounting and valuation, so that for a long period of time the firm could not invest in Turkish local currency. The value of such investments had to be large enough for the firm to incur the costs of system redesign.

Finally, issues such as the overall personal safety in the country, along with amenities such as adequate hotels, sanitary food and water, etc., play a significant role in determining whether an international investor will visit a country. As such, some investors we interviewed will rule out investing in a country if they feel unable to initially learn first hand information about it, which they may not try to do if they feel unable to travel there without risk. Of course, this matter relates to the rule of law, an important subjective criteria element mentioned earlier.

\subsection{SIZE}

For investors dealing in emerging market assets, especially bonds, size matters in a few different ways. In the first sense, the size issue relates to whether the country issues debt or equity in a significant enough quantity to make it worthwhile for an investor to research the credit. As described earlier, the research process for both determining investability of a credit combined with the cost of ongoing research suggests that the size of the investment must pass some critical threshold within the portfolio to warrant inclusion. For an asset manager with USD 500 million plus in emerging market assets, the ability to invest USD 10 million in a bond does only in very few cases carry a high enough expected return to make it worthwhile putting the credit under coverage. Secondly, the size of the country's marketable assets, whether in total or pertaining to an issue, must be large enough to either allow for a diversification effect - a meaningful contribution to lowering total portfolio risk - or high enough return to affect overall portfolio profitability. Since funds will have limits for how much of an individual issue they can invest in - commonly around a max of $10 \%$ - total issue sizes under USD 150 to 200 million remain unattractive to many large emerging market investors. Even without internal limits, for these small issuances, the large investors may find it difficult to be allocated a sufficient size due to competition with other investors.

In another sense, country or economic size serves as a proxy for a host of subjective measures, which serve to describe the political stability or business environment in the country. For example, poorer countries tend to be those that suffer more from corruption, human rights violations, income inequality, and often an unstable political regime. Rather than analyze a country's record on each of these fronts, many investors basically do not consider countries that fall below a certain GDP per capita level. That said, when a small country suddenly appears in international 
capital markets with a significant enough issue (perhaps USD 250 million or more), it will garner interest if only it presents diversification to some of the smaller investment funds, and if (and this is an important if) the country has a good enough story-line that investors feel confident they will get paid on their investment. Some large funds may invest in a package of bonds with similar characteristics only based on their statistical propensities, i.e., their contribution to diversification of the portfolio, without putting the credit under coverage. Some of the managers in our sample indicated in this manner they had participated in the recent Dominican Republic and Jamaica bond markets by buying a bundle of the two issues, with only a cursory macro risk analysis of the individual countries.

Some investors also rely more heavily on liquidity in the secondary market, and use the size of the issue as a proxy for market liquidity. As size is not a necessary condition for liquidity these investors also indicated they looked at the underwriters and their track records in supporting an issue before investing.

\section{POLICY IMPLICATIONS}

As discussed above, we have found that countries fall into the categories of "must," "may", or "cannot" invest. Countries can adopt policies in a number of areas which can affect their standing across these categories, and their degree of investability. Table 2 that lists some selected factors that influence the investability decision for a majority of the international portfolio investors included in this study. While the list captures many of the important factors, it is not exhaustive, and it may change over time.

In the few cases where U.S. or international sanctions govern, or where specific client-mandated socially responsible investing requirements bind, will portfolio flows be completely ruled out. Only very fundamental policy shifts (either domestically or internationally) will enable these countries in the "cannot" invest category to become investable. While other policies can be perused, which may affect the attractiveness of the country once it has moved from the "cannot" to the "may" invest category, they will typically not make the country investable.

Furthermore, there are not many decisive actions a country can take in order to become part of the "must invest" group; indeed, for bond markets, this status can be rather perversely pejorative and inconsistent with a country's credit quality. "Must invest" countries are typically large countries with - on the equity side - large global locally and internationally listed companies and - on the bond side - a large quantity of international government bond issues. For equity markets, a large weight in the benchmark can be representative of a more well developed market and should be correlated with a higher investment standard internationally. For bond markets, a large weight in the benchmark can be representative of an excessive borrowing requirement, which increases the country's credit risks and financing costs. 


\begin{tabular}{|c|c|}
\hline \multicolumn{2}{|c|}{ Table 2: Selected factors influencing the investability decision } \\
\hline \multicolumn{2}{|l|}{ "Housekeeping": } \\
\hline $\begin{array}{l}\text { Macroeconomic condi- } \\
\text { tions }\end{array}$ & $\begin{array}{l}\text { - GDP growth } \\
\text { - Inflation } \\
\text { - Trade and current account } \\
\text { Financing of the current account }\end{array}$ \\
\hline $\begin{array}{l}\text { Political econ- } \\
\text { omy/stability }\end{array}$ & $\begin{array}{l}\text { - Transparency: access to information and policy makers } \\
\text { - Well established process for political change } \\
\text { - History of paying obligations, also after change in government }\end{array}$ \\
\hline Quality of Local Financial & - Health, quality and stability of the financial system \\
\hline Markets & $\begin{array}{l}\text { - Depth and breath of local investor base (providing high quality information as } \\
\text { well as counterparts for secondary trading) }\end{array}$ \\
\hline Corporate Governance & $\begin{array}{l}\text { - High transparency of corporate accounts } \\
\text { - } \quad \text { Alignment of interests between management and (minority) shareholders }\end{array}$ \\
\hline \multicolumn{2}{|l|}{ "Plumbing": } \\
\hline Legal and Regulatory & - Rule of law \\
\hline Framework & $\begin{array}{l}\text { - } \quad \text { Strength of judiciary } \\
\text { - } \quad \text { English language in legal documents } \\
\text { - } \quad \text { Consequences of non-compliance clearly defined }\end{array}$ \\
\hline $\begin{array}{l}\text { Custody, clearing and } \\
\text { settlement }\end{array}$ & $\begin{array}{l}\text { - Recognition of sub-custodians } \\
\text { - Sub-custodian able to represent the interest of the final owner } \\
\text { - } \quad \text { Clears implementation of finality in registration of ownership } \\
\text { - Low settlement costs }\end{array}$ \\
\hline Taxes & - Clear tax code / low taxes (including stamp duties) \\
\hline Other plumbing factors & $\begin{array}{l}\text { - Repo'ability of local (fixed income) investments } \\
\text { - Personal safety and adequate amenities }\end{array}$ \\
\hline \multicolumn{2}{|l|}{ Size: } \\
\hline $\begin{array}{l}\text { Economy } \\
\text { Issue }\end{array}$ & $\begin{array}{l}\text { - } \quad \text { GDP per Capita } \\
\text { - } \quad \text { Size of total investable issues/assets } \\
\text { - }\end{array}$ \\
\hline
\end{tabular}

The pervasive use of modeling and quantitative analysis results in the first lesson for emerging market policymakers: putting effort into developing and disseminating a broad range of reliable data, and providing investor access on a non-preferential basis to bureaucrats and politicians, will have a positive impact on the investability of the country. As mentioned above, investors are looking for timely data, for a variety of frequencies (weekly, monthly, annually, etc.), for as long a history possible. Without such data provision, a country will find itself un-investable from the start.

Second, countries should pay attention to ensuring that the plumbing is working efficiently. Here, marginal changes are not too costly or time consuming, and can have a significant affect on attracting flows, especially into local currency investments. In particular, countries should work toward promoting safe and efficient custody arrangements (ensured through a good regula- 
tory framework), standardized documentation for trading, clear tax laws, the use of the English language in both financial and legal documents, and well defined and enforceable property rights (regarding registration of ownership, control of assets - especially in terms of bankruptcy code, a legal separation between client and proprietary assets, etc) as well as ensuring a well functioning repo market.

Perhaps the most important avenue a country can pursue is to develop its local financial markets, particularly the local investor base. For a government's debt management and financing purposes, a deep local investor base will provide additional stability of financing, and less susceptibility to external shocks. These reasons will also help attract international investors to the country. In addition, positive externalities, such as increased information sources and a higher number of counterparties (and resulting higher liquidity), will increase a country's investability. Policies that countries can follow to achieve a deeper investor base include pension and insurance reform, efforts to reach retail investors (such as electronic distribution initiatives), and the quality of plumbing issues listed above.

Finally, given the characteristics of the bulk of the international investment funds, some conclusions can be drawn for the small countries. In general, a country's marginal contribution to an even medium-sized portfolio in terms of diversification or yield must be large enough to cover the extensive costs of analyzing it. Hence, smaller countries will do better not targeting the larger investors in New York and Boston, but rather going for the smaller emerging market investors working out of less high-profile places. For example, these countries can find a growing pool of investors in their own neighborhood, those in the region rather than in the international financial centers. Targeting of alternative investors is also pertinent due to the design of benchmark indices that tend to be used by the large institutional investors; benchmarks require a minimum issue size and quantity of outstanding debt that will be impossible for many small countries to fulfill.

Small improvements in any of the above-mentioned areas can have a large impact on the portfolio allocation decisions. All the models discussed produced not only a non-linear convex relationship between expected return and risk (e.g., as risk increases, the expected required return increases even more), but also a discretionary kink (see Figure 1). Hence, for a country on the "may invest" list, improvements in data provision, plumbing, and the development of the local financial markets can have a high payoff in terms of making the country investable, and will result in lower financing costs and increased portfolio flows through time.

\section{CONCLUSIONS}

This paper relied on interviews with various international investors to document the factors that impact the investability of emerging markets, and the role that the investment process plays in asset allocation. We concluded that the most important factors that attract portfolio flows into emerging markets are of the "housekeeping" nature: macroeconomic policies geared toward growth enhancement and stable, predictable political regimes that foster human and economic 
development. Second, "plumbing" factors, such as quality of information about the country, the legal and regulatory framework, settlement and registration facilities, and the quality of the local financial markets, critically affect the investability assessment, especially for small and mediumsized economies. Table 2 provides a summary of selected "housekeeping" and "plumbing" factors influencing the investability decisions. Finally, the investment process has become more rigorous, explicit, and consequently more data intensive over the past 10 years. The trend has been to quantify subjective indicators that were previously incorporated in a "touchy-feely" way. As investors have demanded more information, countries, multilateral institutions and independent vendors have supplied more, and the asset allocation process has changed.

Future research in this area could expand the universe of investors (specifically to include investors outside the main financial centers and local to the emerging market regions, as well as a wider variety of equity investors) to further refine the analysis in order to differentiate the investability criteria and process across investor types. Institutional investor databases containing portfolio flow information across countries could be exploited to empirically test the relative importance of the factors identified in this paper in relation to the binary investability decision. 


\section{BIBLIOGRAPHY}

Aggarwal, R., Klapper, L., and Wysocki, P., 2003. "Portfolio Preferences of Foreign Institutional Investors." World Bank mimeo.

Ades, A., R. Masih and D. Tenengauzer, 1998, "A New Framework for Predicting Financial Crises in Emerging Markets," Goldman Sachs.

Bailey, Warren, U. Peter Chung, and Jun-Koo Kang, 1999, "Foreign Ownership restrictions and equity price premiums: What drives the demand for cross border investments?" Journal of financial Quantitative Analysis 34, 489-512

Bank for International Settlements, 2003a. "Incentive structures in institutional asset management and their implications for financial markets", Committee on the Global Financial System.

Bank for International Settlements, 2003b. International banking and financial market developments. BIS Quarterly Review, September 2003.

Bekaert, G., 1995. "Market Integration and Investment Barriers in Emerging Equity Markets." World Bank Economic Review 9, 75-107.

Bekaert, G., and Harvey, C.R., Lumsdaine, R., 2002. "The Dynamics of Emerging Market Equity Flows. Journal of International Money and Finance 21, 295-350.

Bekaert, G., Harvey, C.R. 1995. “Time-varying World Market Integration.” Journal of Finance 50, 403-444.

Bekaert, G., Harvey, C.R. 2000. "Capital Flows and the Behavior of Emerging Market Equity Returns," in Sebastian Edwards, ed., Capital Inflows to Emerging Markets, NBER and University of Chicago Press, 159-194.

Bohn, Henning, and Linda L. Tesar, 1996. "U.S. Equity Investment in Foreign Markets: Portfolio Rebalancing or Return Chasing?" The American Economic Review, Vol. 86, No. 2, 77-81.

Borensztein, Eduardo, and R. Gaston Gelos, 2000, "A Panic Prone Pack? The Behavior of Emerging Market Mutual Funds,” IMF Working Papers, No. 00/198.

Brennan, Michael J, and H. Henry Cao, 1997, "International Portfolio Investment Flows" Journal of Finance 52, 1851-1880

Choe, H., Kho, B.C., Stulz, R. 1999. "Do Foreign Investors Destabilize Stock Markets? The Korean Experience in 1997.” Journal of Financial Economics 54, 227-264.

Dahlquist, Magnus and Goran Robertsan: Direct Foreign Ownership, Institutional Investors, and Firm Characteristics, Journal of Financial Economics 59 (2001), 413-440.

Donohue, Jessica T and Kenneth A. Froot, 2002. "The persistence of emerging market equity flows" NBER Working Papers 9241, National Bureau of Economic Research, Inc. 
Durham, J. Benson, 2000.- A Survey of the Econometric Literature on the Real Effects of International Capital Flows in Lower Income Countries, QEH Working Paper 50, University of Oxford

Froot, Kenneth A., and Paul G.J. O'Connell \& Mark S. Seasholes, 2001. "The Portfolio Flows of International Investors". Journal of Financial Economics 59, 151-194.

Gelos, Gaston R., and Shang-Jin Wei. 2002. "Transparency and International Investor Behavior”, NBER Working Paper 9260, National Bureau of Economic Research, Inc.

Gordon, J., and Gupta, P. 2003. "Portfolio Flows into India: Do Domestic Fundamentals Matter?” IMF Working Paper 03/20.

Green, Duncan, 2003. "Do UK Charities Invest Responsibly? A Survey of Current Practice", Just Pensions, London.

Hummels, Harry and Diederik Timmer, 2003. "Money and Morals, The development of Socially Responsible Investing among Dutch Pension Funds", University of Nyenrode.

Impavido, Gregorio, Alberto R. Musalem, and Thierry Tressel, 2003, "The Impact of Contractual Savings Institutions On Securities Markets”, World Bank Policy Research Working Paper 2948

Kaminsky, Graciela, Richard Lyons and Sergio Schmukler, 2000. "Managers, investors, and crises: Mutual Fund Strategies in Emerging Markets", NBER Working Papers 7855, National Bureau of Economic Research, Inc.

Kaminsky, Graciela, Richard Lyons and Sergio Schmukler, 2000. "Mutual Fund Investment in Emerging Markets: An Overview”, World Bank.

Kaminsky, G. and C. Reinhart, 1999, "Papers on Crises and Contagion, The Twin Crises: The Causes of Banking and Balance of Payment Problems," American Economic Review 89, 473500 .

Kim, W., Wei, S.J., 2002. "Foreign Portfolio Investors before and during a Crisis." Journal of International Economics 56, 77-96.

Lane, Phillip R and Gia http://www.imf.org/external/pubs/ft/staffp/2002/00-00/pdf/lane.pdf

Levine, R., and Zervos, S., 1998. "Capital Control Liberalization and Stock Market Development," World Development, August, 1169-1183.

"OECD Principles of Corporate Governance", 1999, Organization for Economic Co-operation and Development, Paris. www.oecd.org/dataoecd/47/50/4347646.pdf

Pope, P. and P. K. Yadav. 1994. "Discovering Error in Tracking Error." Journal of Portfolio Management, Winter 1994, 27-32

Portes, R and H Rey, 2000. "The Determinants Of Cross-Border Equity Flows," CEP Discussion Papers, Centre for Economic Performance, LSE.

Rofman, Rafael, 2002. "The Pension System and the Crisis in Argentina: Learning the Lessons". Background paper of Regional Study on Social Security Reform, Office of the Chief Economist, Lating America and Caribbean Region, The World Bank. 
Roll, R., 1992. "A Mean/Variance Analysis of Tracking Error.” Journal of Portfolio Management, 13-22.

Social Investment Forum, 2001. "2001 Report on Socially Responsible Investing Trends in the United States", Social Investment Forum, Washington, D.C.

Tesar, L., and Werner, I., 1995. "Ü.S. Equity Investment in Emerging Stock Returns." World Bank Economic Review 9, 109-130.

Vittas, D., 2003. "The Use of "Asset Swaps" by Institutional Investors in South Africa", World Bank Working Paper (forthcoming)

Warther, V.A., 1995. "Aggregate Mutual Fund Flows and Security Returns.: Journal of Financial Economics 39, 209-235.

Wilshire Consulting, 2003. "Permissible Equity markets Investment Analysis and Recommendations". Prepared for The California Public Employees' Retirement System, Wilshire Associates. http://www.calpers.ca.gov/whatshap/calendar/board/invest/200302/Item06b-01.2.pdf 


\section{APPENDIX 1 CALPERS PERMISSIBLE COUNTRY LIST: COUNTRY AND MARKET FACTORS}

\begin{tabular}{|c|c|c|c|}
\hline & & & Data Source \\
\hline \multicolumn{4}{|c|}{ Country Factor $(50 \%)$} \\
\hline \multicolumn{4}{|c|}{ 1. Political Stability (17\%) } \\
\hline 1.a & Civil Liberties & $\begin{array}{l}\text { Freedom of expression, association and organizational rights, rule } \\
\text { of laws, human rights, free trade unions and effective collective } \\
\text { bargaining }\end{array}$ & $\begin{array}{l}\text { Freedom House } \\
\text { (http://www.freedomhouse.org/ratings/index.htm) }\end{array}$ \\
\hline 1.b & $\begin{array}{l}\text { Independent Judiciary } \\
\text { and Legal Protection }\end{array}$ & $\begin{array}{l}\text { Absence of irregular payments to judiciary, legal framework hon- } \\
\text { oring contracts and delineates ownership of and protects financial } \\
\text { assets }\end{array}$ & $\begin{array}{l}\text { World Economic Forum: Global Competitiveness Report } \\
\text { (www.weforum.org/gcr) }\end{array}$ \\
\hline 1.c & Political Risk & $\begin{array}{l}\text { Internal and external conflict, corruption, military and religion in } \\
\text { politics, law and order ethnic tensions, democratic accountability } \\
\text { and bureaucratic quality }\end{array}$ & $\begin{array}{l}\text { PRS Group: International Country risk Guide } \\
\text { http://www.prsgroup.com/icrg/icrg.html }\end{array}$ \\
\hline \multicolumn{4}{|c|}{ 2. Transparency (16\%) } \\
\hline 2.a & Freedom of the Press & $\begin{array}{l}\text { Degree of political influence and control, economic influence, } \\
\text { physical violations and censorship }\end{array}$ & $\begin{array}{l}\text { Freedom house Press Freedom Survey } \\
\text { (www.freedomhouse.org) }\end{array}$ \\
\hline 2.b & Accounting Standards & Financial reporting using either U.S. GAAP or IAS & $\begin{array}{l}\text { IASB (International Accounting Standards Board } \\
\text { http://www.iasb.org.uk/) and IFAD (International Forum } \\
\text { on Accountancy Development) http://www.ifad.net/ }\end{array}$ \\
\hline 2.c & $\begin{array}{l}\text { Monetary and Fiscal } \\
\text { Transparency }\end{array}$ & $\begin{array}{l}\text { Clear and timely availability of information regarding monetary } \\
\text { and fiscal policies in accordance with international standards }\end{array}$ & Oxford Analytica \\
\hline 2.d & $\begin{array}{l}\text { Stock Exchange List- } \\
\text { ing Requirements }\end{array}$ & $\begin{array}{l}\text { Frequency of financial reporting, annual independent audits and } \\
\text { minimum financial viability for new listings }\end{array}$ & $\begin{array}{l}\text { IASB, IFAD, and Euromoney Gude to World Equity } \\
\text { Markets http://www.euromoneyplc.com/ }\end{array}$ \\
\hline \multicolumn{4}{|c|}{ 3. Productive Labor Practices (17\%) } \\
\hline 3.a & ILO Ratification & $\begin{array}{l}\text { Extent to which the country has International Labor Organizations } \\
\text { (ILO) ratification of the eight core conventions covering the topics } \\
\text { of forced labor, freedom of association, discrimination, and child } \\
\text { labor. }\end{array}$ & $\begin{array}{l}\text { Verite: www.verite.org } \\
\text { www.ilo.org } \\
\text { (http://webfusion.ilo.org/public/db/standards/normes/appl }\end{array}$ \\
\hline
\end{tabular}




\begin{tabular}{|c|c|c|c|}
\hline 3.b & $\begin{array}{l}\text { Quality of Enabling } \\
\text { Legislation }\end{array}$ & $\begin{array}{l}\text { Evaluation of whether laws exist that either explicitly protects or } \\
\text { prohibits the rights covered by the ILO conventions }\end{array}$ & \multirow[t]{3}{*}{ /appl-ratif8conv.cfm?Lang=EN\#8ratif) } \\
\hline 3.c & Institutional Capacity & Administrative bodies with labor law enforcement responsibility & \\
\hline $3 . \mathrm{d}$ & $\begin{array}{l}\text { Effectiveness of Im- } \\
\text { plementation }\end{array}$ & $\begin{array}{l}\text { Existence and use of grievance process; penalties levied in prac- } \\
\text { tice; evidence that penalties have deterrence value }\end{array}$ & \\
\hline \multicolumn{4}{|c|}{ Market Factors $(50 \%)$} \\
\hline \multicolumn{4}{|c|}{ 4. Market Liquidity and Volatility (12.5\%) } \\
\hline 4.a & \multicolumn{2}{|c|}{ Market Capitalization } & \multirow[t]{4}{*}{ S\&P Emerging Stock markets Factbook } \\
\hline 4.b & \multicolumn{2}{|c|}{ Change in Market Capitalization } & \\
\hline 4.c & \multicolumn{2}{|c|}{ Average Monthly Trading Volume } & \\
\hline 4.d & \multicolumn{2}{|c|}{ Growth in Listed Companies } & \\
\hline 4.e & \multicolumn{2}{|c|}{ Market volatility $\left(\sigma^{2}\right)$} & \multirow[t]{2}{*}{ Wilshire Compass (http://www.wilshirecompass.com/) } \\
\hline 4.f & Return/Risk Ration & $\begin{array}{l}\text { Percentage of total return achieved per percentage of risk }\left(\sigma^{2} \text { of }\right. \\
\text { returns) in the market }\end{array}$ & \\
\hline \multicolumn{4}{|c|}{ 5. Market Regulation/Legal System/Investor Protection (12.5\%) } \\
\hline $5 . \mathrm{a}$ & \multicolumn{2}{|c|}{ Adequacy of Financial Regulation } & Global Competitiveness Report \\
\hline $5 . \mathrm{b}$ & \multicolumn{2}{|c|}{ Bankruptcy/Creditors Rights } & Oxford Analytica \\
\hline 5.c & \multicolumn{2}{|l|}{ Shareholders Rights } & \\
\hline \multicolumn{4}{|c|}{ 6. Capital Market Openness (12.5\%) } \\
\hline $6 . \mathrm{a}$ & \multicolumn{2}{|l|}{ Trade Policy } & \multirow{3}{*}{$\begin{array}{l}\text { The Heritage Foundation's and the Wall Street Journal's } \\
\text { Index of Economic Freedom } \\
\text { (http://www.heritage.org/research/features/index/) }\end{array}$} \\
\hline $6 . \mathrm{b}$ & \multicolumn{2}{|l|}{ Foreign Investment } & \\
\hline 6.c & \multicolumn{2}{|l|}{ Banking and Finance } & \\
\hline $6 . d$ & \multicolumn{2}{|c|}{ Stock Market Foreign Ownership Restrictions } & S\&P Emerging Stock markets Factbook \\
\hline \multicolumn{4}{|c|}{ 7. Settlement Proficiency/Transactions Costs (12.5\%) } \\
\hline 7.a & \multicolumn{2}{|c|}{ Settlement Proficiency } & Euromoney Guide to World Equity Markets \\
\hline $7 . \mathrm{b}$ & \multicolumn{2}{|l|}{ Transaction Costs } & S\&P Emerging Stock markets Factbook \\
\hline
\end{tabular}

